\title{
Cryopreservation of Semen From Functional Sex-Reversed Genotypic Females of the Rainbow Trout, Oncorhynchus mykiss
}

\author{
Alexandre Ninhaus-Silveira ${ }^{1 *}$, Fausto Foresti $^{2}$, Yara Aiko Tabata ${ }^{3}$, Marcos Guilherme \\ Rigolino $^{3}$ and Rosicleire Veríssimo-Silveira ${ }^{2}$ \\ ${ }^{1}$ Departamento de Biologia e Zootecnia; UNESP; Ilha Solteira - São Paulo - Brasil. ${ }^{2}$ Departamento de Morfologia; \\ UNESP; IB; Botucatu - São Paulo - Brazil. ${ }^{3}$ Estação Experimental de Salmonicultura; APTA; Campos do Jordão - \\ São Paulo - Brasil
}

\begin{abstract}
Cryopreservation of semen from sex-reversed females of rainbow trout aims at rationalizing the production of stocks composed by $100 \%$ females. Semen from normal males $(M)$ and two types of genotypic females $(R$ and $G)$, sex-reversed by the oral administration of $17 \alpha$-methyltestosterone, were used. $R$ was obtained by the fertilization of normal eggs with semen of sex-reversed females while $G$ via gynogenetic reproduction. Semen was diluted in an extender solution (glucose 5,4 g, egg yolk $10 \mathrm{ml}$, dimetil sulfoxide $10 \mathrm{ml}$, water $80 \mathrm{ml}$ ) at 1:3 ratio (semen/extender), stored in straws of $0.5 \mathrm{ml}$ and freezed in a dry container Cryopac CP-65, at $-180^{\circ} \mathrm{C}$. Thawing was performed with water at $70^{\circ} \mathrm{C}$ for 3 seconds. There were no significant fertilization rate differences $(P>0.05)$ among thawed semen groups $(M=73.1 \pm 11.5 \% ; R=67.2 \pm 23.6 \% ; G=64 \pm 5.8 \%)$, confirming that the freezing methodology used was efficient to cryopreserve semen of all three trout groups.
\end{abstract}

Key words: Oncorhynchus mykiss, Cryopreservation, Sex reversal, Gynogenesis, Semen

\section{INTRODUCTION}

Sex maturation of fishes is related to modifications that lead to reduction of growth and decreasing of product quality, because of the high energy demand for gonad development. In salmonids, these problems are more concerned to males, since they usually become mature before reaching the commercial size. Therefore, production of "all female" populations constitutes an useful alternative to improve productivity and quality of commercial stocks (Bye and Lincoln, 1986). The procedure commonly performed to produce stocks composed by $100 \%$ of females, comprises sex reversal of females by administration of $17 \alpha-$ methyltestosterone in early development stages, followed by fertilization of eggs from normal females with semen samples from reversed ones (Hunter et al., 1983; Tsumura et al., 1991).

Demand for female monosex lines has been increasing over the last years, requiring the development of specific technologies to standardize this process, aiming to increase the production of sex-reversed females. Cryopreservation of semen from sex-reversed genotypic females with $17 \alpha$-methyltestosterone (MT) might, thus, contribute to rationalization of the production of all-female rainbow trout stocks,

* Author for correspondence 
as it improves semen utilization and reduces hormone treatments, assuring a regular supply of such material.

Studies involving semen freezing of rainbow trout were reported by several authors (Stoss et al., 1978; Stoss, et al., 1983; Baynes and Scott, 1987; Wheeler and Thogaard, 1991; McNiven et al., 1993; Fogli da Silveira et al, 1994; Conget et al., 1996; Cabrita et al., 2001). However, the number of reports related to utilization and application of the semen obtained from reversed females is scarce (Kavamoto et al., 1991; Feist et al., 1995; Tabata and Mizuta, 1997; Robles et al., 2003).

The present work evaluated the fertility of cryopreserved semen from functional sex-reversed genotypic females of the rainbow trout, Oncorhynchus mykiss, aiming to form a semen bank to be used in programs of production of monosex female stocks of this species.

\section{MATERIALS AND METHODS}

This work was carried out at the Estação Experimental de Salmonicultura, APTA/ Regional do Vale do Paraíba, State of São Paulo, Brazil, located in Campos do Jordão. Milt samples were collected from normal males (M) and from two types of genotypic females, which were sexreversed by oral administration of $17 \alpha$ methyltestosterone (MT), at a dose of $250 \mu \mathrm{g} / \mathrm{kg}$ food, during 80 days at a mean temperature of $12.8^{\circ} \mathrm{C}$ (Accumulated Thermal Units (ATU) $=$ $1024^{\circ} \mathrm{C} /$ days), starting from the beginning of feeding. (Tabata et al., 2000).

The first type of genotypic female was obtained by fertilizing of normal eggs with semen of reversed females (R). The second type $(\mathrm{G})$ was a result of gynogenetic reproduction, where the eggs were fertilized with spermatozoa previously irradiated with ultraviolet light (UV) and then diploidized by the retention of the second polar body after thermal shock at $28^{\circ} \mathrm{C}$. When two years old (first maturation), the fishes that expelled milt by abdominal pressing were selected as breeders.

Motility of spermatozoa was evaluated on a subjetive scale ranging from 0 to 5 , where the lowest value indicated samples without motile spermatozoa and the highest value referred to those samples with up or more than $80 \%$ of motility (Fribourg, 1966). Sperm concentration (spermatozoa $/ \mathrm{mm}^{3}$ ) was determined by a
Neubauer chamber (1:1000; semen:extender). Motility and concentration of semen samples were analyzed in order to evaluate the cryopreservation procedure. Samples with level 5 of motility were grouped as a pool and further evaluated about their spermatozoa concentration. Four donors were used to compose the sperm pool in each semen producer group. Semen was diluted in a cryoprotectant extender composed by $5.4 \mathrm{~g}$ of glucose, $10 \mathrm{ml}$ of chicken egg yolk, $80 \mathrm{ml}$ of water and $10 \mathrm{ml}$ of dimethyl sulfoxide (DMSO). Semen dilution was performed at room temperature $\left(14^{\circ} \mathrm{C}\right.$ ), in a proportion of $1: 3$ (semen: extender). After dilution, semen was stored in straws of 0.5 $\mathrm{ml}$ and immediately frozen in liquid nitrogen in a dry container (CryoPac / CP-65 - Taylor-Warton) at $-180^{\circ} \mathrm{C}$ without a previous equilibrium of semen to the cryoprotectant extender. After freezing, straws containing semen samples were transferred to a wet container (Cryometal/DS-34) for cryopreservation $\left(-195^{\circ} \mathrm{C}\right)$.

Fertilization tests were performed 24 hours after semen freezing. About 150 eggs were taken from a pool of eggs from four two years old females and were fertilized with thawed semen (two straws/sample). Fresh semen from three new groups of donors, composed by four normal males (M) and eight sex-reversed females (4R and $4 \mathrm{G}$ ) were used in the treatment control. For these treatments, $0.2 \mathrm{ml}$ of semen/sample was added. Four replicates were performed for each treatment. Semen was thawed with water at $70^{\circ} \mathrm{C}$ for $3 \mathrm{~s}$, and immediately mixed to the eggs and activated with a solution of $\mathrm{NaHCO}_{3} 1 \%$. After 20 minutes of activation, the eggs were ringed with tap water and kept in incubators. Fertilization rate was determined after 17 days of incubation, with $196^{\circ} \mathrm{C} /$ days, when the embryos presented pigmented eyes (eyed eggs), and estimated by the ratio between viable eggs and the total number of eggs per sample.

In order to compare the fertility rate of the frozen/thawed semen among the three studied groups (normal males (XY) and the two types of sex-reversed genotypic females $(\mathrm{XX})$ ) a multiple way analysis of variance - ANOVA $(\alpha=0.05)$, complemented by the Tuckey's test $(\alpha=0.05)$ was applied. The software SAS version 8.02 was adopted. 


\section{RESULTS AND DISCUSSION}

Hormonal treatment has been used in fish farming to change the functional sex of specimens. In general, administration of androgens leads to masculine populations, where most of reversed females present incomplete spermatic ducts or lack them, requiring the sacrifice of the fishes to obtain the milt (Tsumura et al., 1991; Geffen and Evans, 2000). Such procedure depends on maintenance of a high number of breeders in fish farms (Robles et al., 2003).

According to Lahnsteiner et al. (1994), the efferent and principal testicular ducts play an important role in storing and nutrition of the spermatozoa, steroids synthesis, seminal fluid ionic composition, auto and heterofagocytic activities, and in the formation of the seminal plasma. Therefore, semen obtained directly from the testis was not completely mature, presents high density, and, probably, several immature cells. It requires, according to Robles et al. (2003), an exogenous maturation prior activation, as the spermatozoa taken directly from the testis were nearly immotile after activation treatment. Thus, production of sexreversed females of rainbow trout presenting spermatic ducts would avoid surgical extraction of the semen, easing the reproduction management, besides reducing the number of stocked breeders (Feist et al. 1995; Tabata et al., 2000).
Semen produced by sex-reversed females of Oncorhynchus mykiss displaying spermatic duct from both stocks showed the same characteristics of semen produced by normal males (low viscosity, milky coloration, spermatic motility at level 5, and high spermatic concentration: $\mathrm{M}=$ $15.925 \times 10^{6}, \mathrm{R}=12.475 \times 10^{6}$ and $\mathrm{G}=14.20 \times 10^{6}$ spermatozoa $/ \mathrm{mm}^{3}$. It was also observed that semen provided by sex-reversed females (R; G) bearing spermatic ducts had the same behavior of that from normal males after freezing and thawing, dispensing the development of specific methodologies towards this source of semen (Table 1).

According to Stoss and Holtz (1983), utilization of frozen semen of rainbow trout, without any previous equilibrium period with the cryoprotectant extender, yielded the best and more reliable fertilization rates. Tabata and Mizuta (1997) observed, by tests with semen of reversed rainbow trout, that there was no correlation between equilibrium time (the period from the semen dilution in the extender to the moment of freezing) and fertility. ANOVA values of $\mathrm{F}=$ 0.353 and $P=0.712$ indicated no significant statistical difference $(P<0.05)$ among the three treatments $(\mathrm{M}=73.1 \pm 11.5 \% ; \mathrm{R}=67.2 \pm 23.6 \%$; $\mathrm{G}$ $=64 \pm 5.8 \%)$ (Fig. 1).

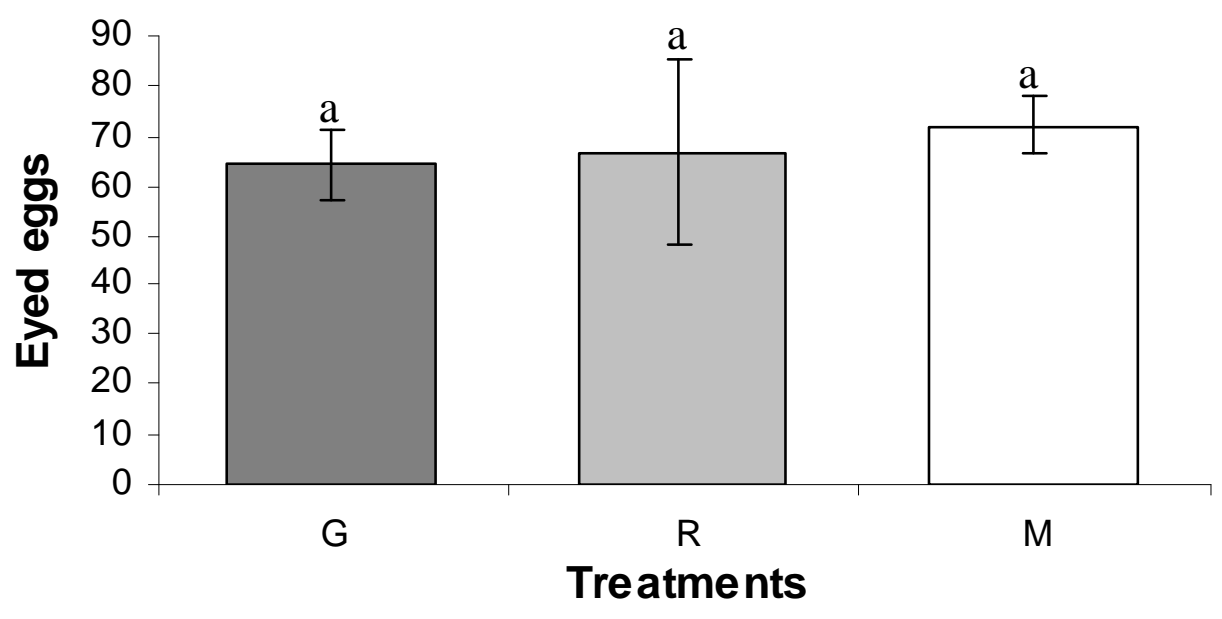

Figure 1 - Relative fertilization rates based on the percentage of eyed eggs for the eggs fertilized with thawed semen from normal males $(\mathrm{M})$ and two types of sex-reversed genotypic females by the oral administration of $17 \alpha$-methyltestosterone $(\mathrm{R}=$ Sex-reversed female; $\mathrm{G}=$ Sexreversed gynogenetic female). 
These results confirmed observations by Stoss and Holtz (1983) and Tabata and Mizuta (1997), as in this experiment there was no previous equilibrium period between the suspension of semen in the cryoprotectant extender and its freezing, and the spermatozoa showed to be sufficiently protected, as inferred by the high rates of embryogenesis with the thawed semen in all treatments (Fig. 1). The equipment used in this work (CryoPac / CP65 -Taylor-Warton) was easily handled for straw freezing, dispensing the verification of the levels of the liquid nitrogen and conserving a constant temperature, thus maintaining a homogeneous freezing rate. Such variables are considered important issues when the freezing process is performed in cooler boxes (Fogli da Silveira et al., 1994, Lahnsteiner et al., 1995, Tabata and Mizuta, 1997; Robles, et al. 2003), where the air volume is high and evaporation of liquid nitrogen is fast. Besides, this equipment is easy to transport, being useful in laboratory as well as in field works.

Table 1 - Fertilization experiment with thawed semen of rainbow trout from normal males and sex-reversed genotypic females. (Control Group $=$ fresh semen)

\begin{tabular}{l|c|c|c|c}
\hline \multicolumn{1}{c|}{ Group } & $\begin{array}{c}\text { Semen Volume } \\
(\mathbf{m L})\end{array}$ & $\begin{array}{c}\text { Sperm/Egg } \\
\text { Ratio }\end{array}$ & $\begin{array}{c}\text { Fertilization } \\
\text { Mean }\end{array}$ & $\begin{array}{c}\text { Rate (mean } \pm \%) \\
\text { Related Mean }\end{array}$ \\
\hline Thawed semen & 1.0 & $2.70 \times 10^{7}$ & $61.33 \pm 5.88$ & $73.11 \pm 11.55$ \\
Male & 1.0 & $2.11 \times 10^{7}$ & $55.52 \pm 18.23$ & $67.16 \pm 23.57$ \\
Sex-Reversed Female & 1.0 & $2.40 \times 10^{7}$ & $56.92 \pm 7.17$ & $64.03 \pm 5.82$ \\
Sex-Reversed Gynogenetic female & & & \\
Fresh semen & 0.2 & $2.15 \times 10^{7}$ & $85.09 \pm 12.82$ & - \\
Male & 0.2 & $1.70 \times 10^{7}$ & $83.12 \pm 4.36$ & - \\
Sex-Reversed Female & 0.2 & $1.92 \times 10^{7}$ & $88.71 \pm 4.14$ & - \\
Sex-Reversed Gynogenetic female & \multicolumn{4}{l}{}
\end{tabular}

**Number of eggs per sample 148.

\section{ACKNOWLEDGEMENTS}

We thank the Estação Experimental de Salmonicultura, APTA, Campos do Jordão, SP, for the facilities and providing biological material, and to CAPES and CNPq for financial support.

\section{RESUMO}

A criopreservação do sêmen de fêmeas masculinizadas de truta arco-íris tem como objetivo a racionalização do processo de produção de estoques $100 \%$ femininos. Para tal, foi coletado sêmen de machos normais (M) e de dois tipos de fêmeas genotípicas ( $\mathbf{R}$ e $\mathbf{G})$, masculinizadas pela administração oral de $17 \alpha$-metiltestosterona. $\mathbf{R}$ foi obtido pela fertilização de ovócitos normais com sêmen de fêmeas masculinizadas enquanto $\mathbf{G}$ foi através de reprodução ginogenética. O sêmen foi diluído em uma solução crioprotetora (glicose 5,4 $\mathrm{g}$, gema de ovo de galinha $10 \mathrm{ml}$, dimetil sulfóxido $10 \mathrm{ml}$, água destilada $80 \mathrm{ml}$ ) na razão de 1:3 (sêmen/diluidor), envasado em palhetas de $0,5 \mathrm{ml}$ e congelado em um "container" tipo "seco" Cryopac $\mathrm{CP}-65$, à temperatura de $-180^{\circ} \mathrm{C}$. A descongelação foi feita em água a $70^{\circ} \mathrm{C}$ por 3 segundos. As taxas de fertilização obtidas, não revelaram diferença estatística significativa $(P<0.05)$ entre os três grupos de sêmen descongelados $\quad(\mathbf{M}=73,1 \pm 11,5 \% ; \quad \mathbf{R}=$ $67,2 \pm 23,6 \% ; \mathbf{G}=64 \pm 5,8 \%$ ), indicando que a metodologia de congelação utilizada foi eficaz, tanto na criopreservação do sêmen das trutas normais como para o das masculinizadas.

\section{REFERENCES}

Baynes, S. M. and Scott, A. P. (1987), Cryopreservation of rainbow trout spermatozoa: the influence of sperm quality and extender composition on post-thaw fertility. Aquaculture, 66, 53-67.

Bye, V. and Lincoln R. (1986), Commercial methods for the control of sexual maturation in rainbow trout (Salmo gairdineiri R.). Aquaculture, 57, 299-309.

Cabrita, E.; Robles, V.; Alvarez, R. and Herráez, M. P. (2001), Cryopreservation of rainbow trout sperm in large straws: application to large scale fertilization. Aquaculture, 201, 301-314.

Conget, P.; Fernandez, M.; Herrera, G. and Minguell, J. J. (1996), Cryopreservation of rainbow trout (Oncorhynchus mykiss) spermatozoa using programmable freezing. Aquaculture, 143, 319-329. 
Feist, G.; Choo-Guan, Y.; Fitzpatrick, M. S. and Schreck, C.B. (1995), The production of functional sex-reversed male rainbow trout with $17 \alpha$-methyltestosterone and $11 \beta$-hydroxyandrostenedione. Aquaculture, 131, 145-152.

Fribourgh, J. H. (1966), The application of a differential staining method to low-temperature studies on goldfish spermatozoa. Progr. Fish Cult., 28 : (4), 227-231.

Fogli da Silveira, W.; Kavamoto, E. T.; Rigolino, M. G.; Arruda Soares, H.; Silveira, A. N. and Veríssimo, R. (1994), Congelação do sêmen de truta arco-íris, Oncorhynchus mykiss, em vapor de nitrogênio líquido. B. Inst. Pesca, 21, 55-60.

Hunter, G.; Donaldson E. M.; Stoss J. and Baker I. (1983), Production of monosex female groups of Chinook salmon (Oncorhynchus tshawytscha) by the fertilization of normal ova with the sperm from sexreversed females. Aquaculture, 33, 355-364.

Kavamoto E. T.; Tabata, Y. A.; Fogli da Silveira, W.; Rigolino, M. G. and Silveira, A. N. (1991). Criopreservação de sêmen de fêmeas genotípicas de truta arco-íris, Salmo gairdnerii, masculinizadas pela $17 \alpha$-metiltestosterona. In: Encontro Brasileiro de Ictiologia, Maringá. Anais... Maringá, PR.

Robles V.; Cabrita E.; Cuñado S. and Herraez M. P. (2003), Sperm cryopreservation of sex-reversed rainbow trout (Oncorhynchus mykiss): parameters that affect its ability for freezing. Aquaculture 224, 203-212.

Stoss, J.; Büyükhatipoglu, S. and Holtz, W. (1978), Short-term and cryopreservation of rainbow trout (Salmo gairdneri, Richardson) sperm. Biol. Anim. Biochem. Biophys., 18, 1077-1082.
Stoss, J. and Holtz, W. (1983a), Cryopreservation of rainbow trout (Salmo gairdneri) sperm. III. Effect of proteins in the diluent, in sperm from different males and interval between sperm collection and freezing. Aquaculture, 31, 275-282.

Tabata, K. and Mizuta, A. (1997), Cryopreservation of sex reversed gynogenetic female sperm hirame. Fisheries Science, 63 : (3), 482-483.

Tabata, Y. A.; Rigolino, M. G. and Nagata, M. K. (2000), Produção de fêmeas masculinizadas de truta arco-íris com ductos espermáticos funcionais. In: Simpósio Brasileiro de Aqüicultura, Florianópolis. Anais... Florianópolis, SC.

Tsumura K.; Blann V. E. and Lamont C. A. (1991), Progeny test of masculinized female of rainbow trout having functional gonoducts. Progr. Fish Cult., 53, 45-47.

Wheeler, P. A. and Thorgaard, G. H. (1991), Cryopreservation of rainbow trout semen in large straws. Aquaculture, 93, 95-100.

Received: June 25, 2004; Revised: September 22, 2005; Accepted: June 01, 2005. 